$58: 1702$

<原 著 $>$

障害肝に拉ける肝切後の 1 核， 2 核肝細胞の

細胞動態に関する検討

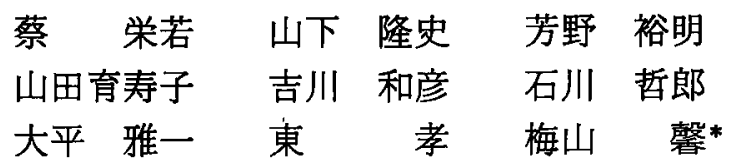

要 旨：障害肝における肝切除後の肝再生について細胞動態の面から検討する目的で, diethylnitrosamine 投与による障害肝ラットを作成し，肝線維症と肝硬变症に分け，70\%肝切除後の mitotic index (MI) ならびに bromodeoxyuridine (BrdU) 用いた 1 核，2核細胞の labeling index (LI) を測定し，正常ラットの肝再生と比較検討した．MIは障害肝でも正常肝と同様の 推移を示し, 肝切48時間後に最も高値を示したが, 肝障害が強くなるほど MI 值は低値を示寸傾 向がみられた. 1 核，2核細胞それぞれの動態をMI で検討することは困難であったので, BrdU のとり込みによるLIについて1核，2核細胞にわけ検討した。 その結果，1核細胞は肝障害の 程度が強くなるに従って LI は低值を示卞傾向がみられた。一方，2核細胞の LI は肝障害の程 度による著明な差はなく，正常肝に比べて低値を示し，肝再生への関与が少ないように思われ た.

索引用語：肝硬変 肝再生 肝 2 核細胞 Mitotic index Labeling index

はじめに

近年, 原発性肝癌に対して比較的安全に外科的切除 がおこなわれるようになったが，肝癌症例の70〜80\% は肝硬変を合併していることから肝障害の程度によっ ては，十分な肝切除がでさないことすある。これには 肝切後の残存肝の機能とともに肝再生が問題となる が1-2),かかる障害肝での肝再生は従来から種々検討さ れているすののな的解明されていない点も多い．著者 らはすでに正常肝の肝切後の肝再生について 1 核， 2 核肝細胞に分けて細胞動態を検討した結果，1核肝細 胞のみならず 2 核肝細胞が重要な役割をはたしている との成績をえているが33，障害肝での肝再生時におけ る 1 核，2核細胞の細胞動熊についての検討はほとん どみられない。

Diethylnitrosamine（DEN）は長期投与すると高率 にヒト肝癌に類似した肝細胞癌の発生がみられ, 短期 投与では種々の程度の肝の線維化を伴う障害肝の作成 が可能であるといわれている、, $。$ そこで今回は DEN

* 大阪市立大学第 1 外科

〈受付日1989年 6 月 27 日 $>$
投与によって作成した障害肝の, 肝切除後の肝再生時 における 1 核， 2 核細胞の細胞動態を中心に検討し， 若干の知見をえたので報告する。

\section{実験動物および実験方法}

1. DEN 障害肝ラットの作成：200〜250g の SD 采 雄性ラットに, DEN を生理食塩水にて溶解し，体重 $\mathrm{kg}$ 当り $80 \mathrm{mg}$ あるいは $100 \mathrm{mg}$ 腹腔内に週 1 回 5 週間連 続投与し，その後 5 週間放置して障害肝ラット（肝障 害群）を作成した。な拉対照として，同量の生理食塩 水のみを投与した群を作成した（対照群）。

2. 肝切除：対照群ならびに肝障害群をエーテル麻 醉下で開腹し, Higgins-Anderson の方法的に準じて約 $70 \%$ 肝切除を扰こない，肝切 $24 ， 48 ， 72 ， 120 ， 240$ 時 間後に屠殺し，肝を摘出した。

なお，肝障害群 (55匹)，対照群 (50匹)のうち各々 15匹，9匹を肝切前群とし，残りのラットを肝切し， 肝切 $24,48,72,120,240$ 時間後に肝障害群は各々 10,9 , $9,6,6$ 匹づつ, 対照群は $11,9,11,5,5$ 匹つつ屠殺 した.

3. Bromodeoxyuridine (BrdU) の投与法：BrdU を生理食塩水で $10 \mathrm{mg} / \mathrm{m} l$ となるように溶解し，屠殺 
1 時間半前に $30 \mathrm{mg} / \mathrm{kg}$ を腹腔内に投与した。

4. 病理組織学的検討：摘出肝を, $70 \%$ タノールで 12時間固定した後, 型のごとくパラフィン包埋後, $4 \mu$ の切片標本を作成し，へマトキシリン・エオシン ( $\mathrm{HE})$ 染色をおこなった。肝障害の程度は Maddenの分類》) に準して，偽小葉を形成したものを肝硬変症とし，偽 小葉の形成がみられなかったものを肝線維症とした。

5. Mitotic index (MI)：HE染色標本を用いて肝細 胞2000個中の核分裂数を算光, 各々 100 個当りの数に換 算し MI とした。

6. Labeling index (LI) : HE 染色用の $4 \mu$ の切片作 成時に，それに連続して作成した切片を用いて多田ら の方法 ${ }^{8)}$ に準し，抗 BrdUモノクローナル抗体 ${ }^{9)}$ 用い て兔疫組織染色をおこなった。肝細胞2000個中の 1 核, 2 核肝細胞を算え, BrdUに標識された 1 核，2核肝細 胞をそれぞれ，100個当りの数に換算し，1核，2核肝 細胞の LI とした.

なお統計学的処理は Studentの T-testを用い, 危険 率 $5 \%$ \%下を有意差有りとした。

\section{1. 病理組織所見}

$$
\text { 成 績 }
$$

$\mathrm{DEN}$ 投与群の訮組織像は全例肝の線維化がみら れ，55匹中35匹（63.6\%）は偽小葉の形成はみられず 線維の幅も狭い肝線維症を呈し，残りの20匹(36.4\%)
は大小不同の偽小葉を伴5肝硬変症であった（図 1 ). なお，この病理所見をととに肝障害群を肝線雓症, 肝硬変症に分けての検討むおこなった（肝線維症では それぞれ 8，7，6，6，4，4匹,肝硬変症ではそれぞれ $7,3,3,3,2,2$ 匹であった).

2. Mitotic index (MI) の変動

Mitosis は肝切前, 肝切後のいずれの時期でも 1 核, 2 核細胞に分けて検討することはきわめて難しかった ので，1核，2核細胞に分けずに検討した，対照群で は肝切前, 肝切24時間, 48時間, 72時間後はそれぞれ $0.02 \pm 0.01 \%, 1.20 \pm 0.50 \%, 1.54 \pm 0.24 \%, 1.25 \pm$

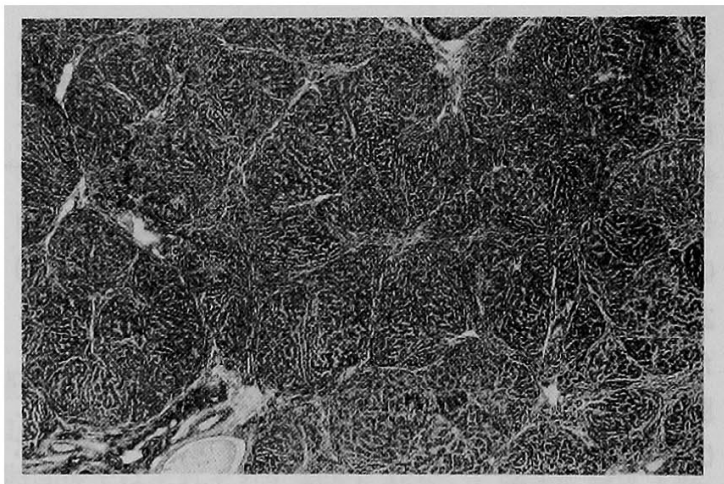

Fig. 1 Histological feature of cirrhosis of the liver in DEN induced chronic liver injured rats (HE stain $\times 100)$.
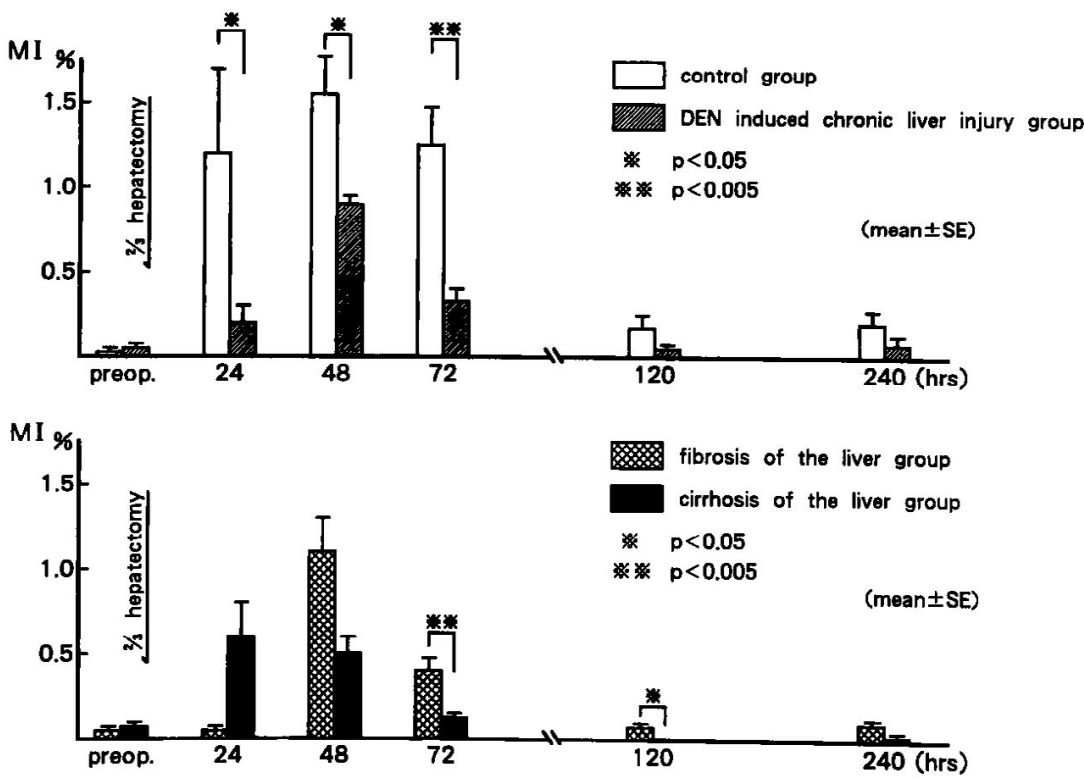

Fig. 2 Changes of mitotic indices after hepatectomy. 
$0.27 \%$ と肝切 48 時間後の $\mathrm{MI}$ が最も高く，その後急速 に低下したが，肝切120時間，240時間後でもそれぞれ $0.17 \pm 0.08 \%, 0.20 \pm 0.07 \%$ と若干分裂像がみられた。 一方, 肝障害群の MI は対照群に比べ低值を示し, MI がビークを示した肝切 48 時間後でも0.90士0.16\%と対 照群に比べ有意に低値を示す傾向がみられた（ $\mathrm{p}<$ 0.05).

肝障害群をさらに肝線維症と肝硬変症に分けてみる と, 肝線維症の MI 值は肝切前, 肝切24時間, 48時間,

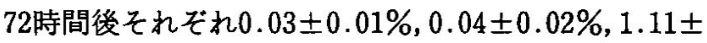
$0.19 \%, 0.40 \pm 0.09 \%$ と対照群と汪ぼ同様のパターン を示したが，肝切48時間後は対照群と差はみられない すのの 24 時間後，72時間後はそれぞれ $2.5 \% ， 0.5 \% の$ 危険率で有意に低值を示した。また120時間，240時間 後でも対照群と有意差はみられなかったが低值を示す 傾向にあった。一方, 肝硬変症の MI 值は, 肝切前, 旰 切24時間，48時間，72時間後それぞれ0.05士0.03\%， $0.62 \pm 0.20 \%, 0.49 \pm 0.12 \%, 0.17 \pm 0.02 \%$ で，肝切 24時間, 48時間後では肝線維症と大差はみられなかっ たが，肝切72時間後では極端に分裂数が少なくなり， 肝線維症より有意に低值を示す傾向にあった（p< 0.025). 120時間後，240時間後にはほ上んど分裂像が 認められなかった（図2）。

\section{Labeling index (LI) の変動}

BrdU がとり込まれた 1 核，2核細胞はとり込まれ ていない細胞と明瞭に識別されたので(図 3)，肝切後
の LI の変動は 1 核， 2 核肝細胞に分けて検討した。

1） 1 核肝細胞の LI の変動：肝切前の 1 核細胞の LI は対照群 $0.04 \pm 0.19 \%$, 肝障害群 $0.70 \pm 0.09 \%$ と， いずれの群です $1 \%$ 以下であったが肝障害群は対照群 より $\mathrm{BrdU}$ の標識率がやや高い傾向にあった. 肝切後 のLIの変化をみると対照群は肝切24時間後26.53士 $3.43 \%, 48$ 時間後 $8.64 \pm 1.90 \%, 72$ 時 間 後 $10.41 \pm$ $1.52 \%$ と肝切 24 時間後に最も高値を示し, 120 時間, 240 時間後ではそれぞれ $1.54 \pm 0.97 \% ， 1.50 \pm 0.65 \%$ とき わめて低値を示した。一方肝障害群は，肝切24，48, 72時間後ではそれぞれ $23.69 \pm 2.49 \% ， 6.24 \pm 1.00 \%$ ， $3.22 \pm 0.37 \%$ で，肝切 24 時間，48時間後では対照群と 差はみられなかったが，72時間後では肝障害群は対照

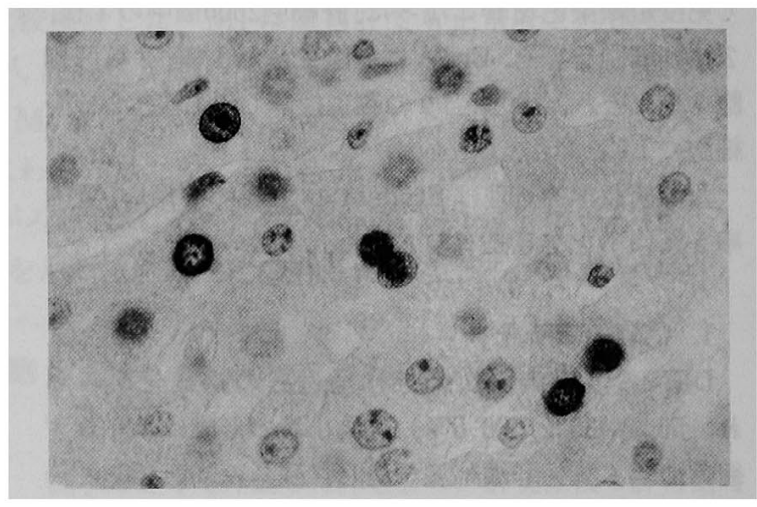

Fig. 3 Uni-and binucleated cells labeled with BrdU (immuno histochemical stain $\times 1,000$ ).

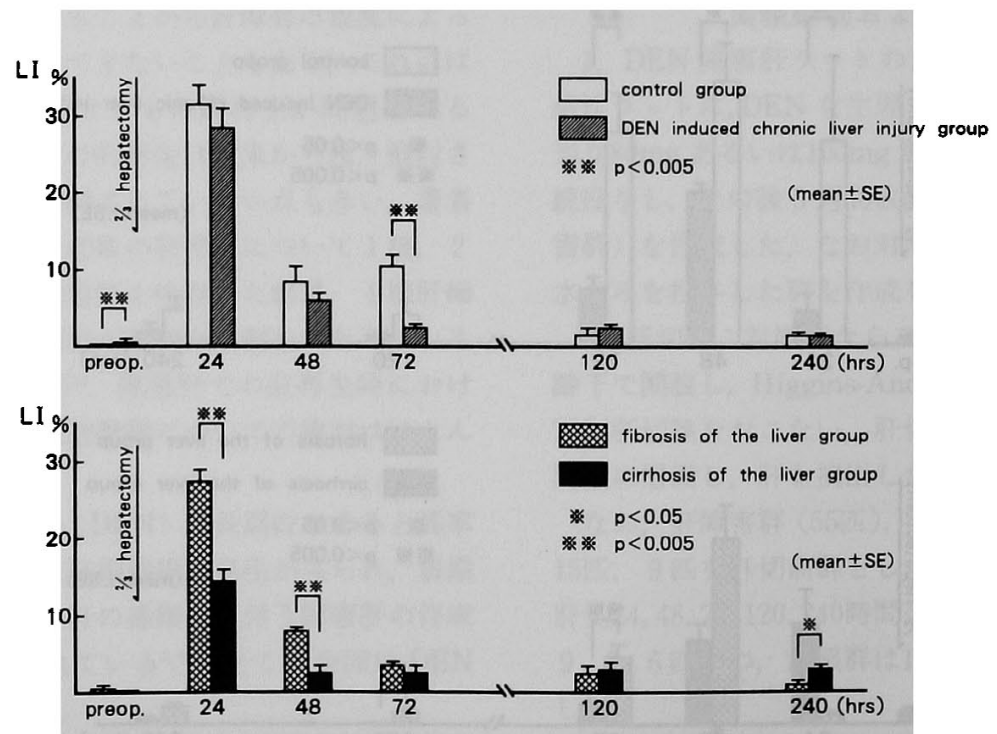

Fig. 4 Changes of labeling indices of uninucleated hepatocytes after hepatectomy. 

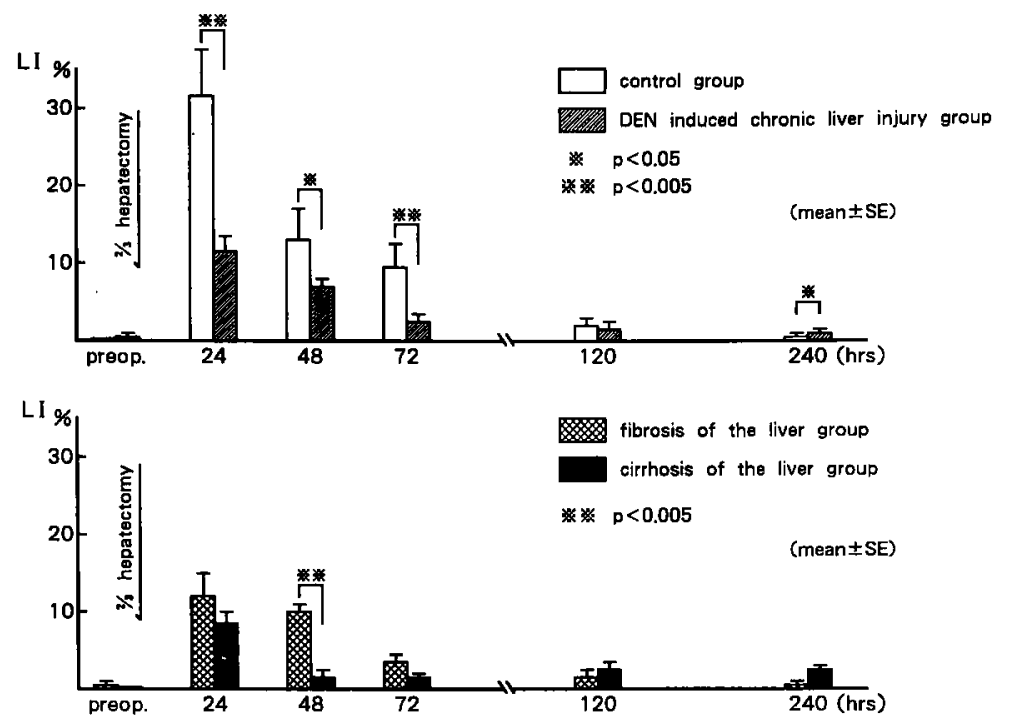

Fig. 5 Changes of labeling indices of binucleated hepatocytes after hepatectomy.

群より有意に低値となる傾向にあった（p<0.005）.

肝障害群を肝線䧽症, 肝硬变症の 2 群に分けて検討 すると，肝線維症は肝切24時間後では $27.61 \pm 2.07 \%$ と 対照群と全く差がみられなかったのに対し，肝硬変症 では $14.53 \pm 1.71 \%$ と肝線維症に比へ有意に低值を示 す傾向がみられた $(\mathrm{p}<0.005)$. また肝切48時間後でも 肝線維症は $7.94 \pm 0.75 \%$ と対照群上りやや低い程度で あったのに対し, 肝硬変症では $2.83 \pm 0.74 \%$ と著明に 低値となり，肝線維症との間に明らかな有意差が認め られた $(\mathrm{p}<0.005)$. その後肝線維症は比較的対照群に 近い推移を示したのに対し, 肝硬変症では肝切48時間 後から LI 值はほとんど変加らず，低值のまま推移す る傾向にあった（因 4 ）。

2） 2 核肝細胞の LI の变動：対照群では肝切前 2 核細胞に BrdUの取り込みがみられなかったが，肝切 24時間後では $31.96 \pm 6.70 \%$ と 1 核肝細胞之同様肝切 24時間後が最も高く, 48時間後では $13.02 \pm 4.04 \%$ とな り，その後標識率は急速に低下する傾向にあった。一 方, 肝障害群では肝切前はわずかにみられたが, 対照 群之有意差はみられなかった。肝切24時間後の LIは $11.24 \pm 2.40 \%$ と対照群の約 $1 / 3$ 程度で対照群に比べ有 意に低く $(p<0.005) ， 48$ 時間後，72時間後もそれぞれ $7.11 \pm 1.66 \% ， 2.93 \pm 0.79 \%$ 之対照群より低值であっ た（それぞれ $\mathrm{p}<0.05, \mathrm{p}<0.005)$.

肝障害群を肝線維症, 肝硬変症に分けて検討すると
肝切24時間後ではそれぞれ $12.40 \pm 3.37 \% ， 8.53 \pm$ $1.46 \%$ と肝硬变症は肝線維症より低值を示し, 肝切 48 時間後ではそれぞれ $9.90 \pm 1.33 \% ， 1.56 \pm 0.94 \%$ と肝 線維症は対照群に近かったが, 肝硬変症は肝線維症よ り有意に低值を示す傾向がみられた $(\mathrm{p}<0.005)$. 肝切 48時間以後は肝線維症は対照群と同様急速に低下し, 240時間後には BrdUのとり込みははとんど䛄められ なかったが, 肝硬变症では240時間後ですな招若干 2 核 細胞に BrdUのとり込みがみられた（図 5).

3) 硬変肝之対照群の肝切除後の肝再生時における LI 值の比較：対照群之硬変肝の LI 值の差を細胞動態 が最も活発な肝切24時間，48時間，72時間後について みると，1核細胞では肝硬変症は対照群より肝切24時 間後で $12.0 \% ， 48$ 時間後で $5.8 \% ， 72$ 時間後で7.7\%低 く，2核細胞ではそれぞれ $23.4 \% ， 11.5 \% ， 12.9 \%$ 低 值を示し, 硬変肝は対照群より 1 核，2核細胞とも LI 值は著明に低值をとる傾向にあった。.とくに硬変肝の 2 核細胞の LI 值は 1 核細胞に比べきわめて低值で あった。

$$
\text { 考 察 }
$$

障害肝での肝再生は正常肝に比へ晴延することが知 られ ${ }^{10 \sim 12)}$, 肝硬変合併肝癌では残存肝の機能以外に肝 再生の遅延もあって広肝囲肝切除が困難なこともあ る.肝再生に関する検討は臨床的に重要な問題であり, 実験的にも正常肝，障害肝を用いて種々検討されてい 
るがな怙明らかでない点も多い．肝再生の検討の多く は盰細胞全体として検討されており，1核，2核肝細 胞に分けて検討された報告は少ない。著者ら3)は正常 肝ラットを用いて肝切除後の, 肝再生時の 1 核， 2 核 肝細胞の細胞動態について検討した結果, 山口ら ${ }^{13)}$, 松 田ら ${ }^{14)}$ の報告と同様に 1 核肝細胞のみならず 2 核細胞 す肝再生に強く関与している成績をえているが，一方， 障害肝に拈ける 2 核細胞については，四塩化炭素12)や DEN 投与硬変肝ラットあるいは七卜肝硬変15) 七卜肝 癌”などの障害肝組織で， 2 核細胞数が减少している ことが報告されている程度で，肝再生時の細胞動態に ついては明かでない。

今回著者らは DEN 投与による障害肝ラットを作成 したが, 障害肝ラットの作成には従来から $\mathrm{CCl}_{4}$, thioacetamide (TTA), diethylnitrosamine (DEN) などが用いられている。その中で DEN は長期投与で 肝癌が，短期投与で障害肝が作成できるといわれ，組 織像も臨床例に比較的近いことから，著者らは DEN を用いた。

なお，2 核細胞数は正常ラットでは週齢によって異 なり，加龄とともに减少するが，今回作成した障害肝 ラットと同時期の 18 週齢前後では 2 核細胞の割合はほ とんど変動がみられない。すた 2 核細胞の割合は flow cytometory あるいは組織切片による検討で若干異な

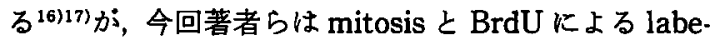
ling indexをみるためWheatley ${ }^{17)}$ と同様 $4 \mu$ の切片標 本を用いて検討した。

障害肝での MI 值は肝切後いずれの時期でも正常肝 に比べ低值であったが，肝線維症と肝硬変症に分けて 検討すると，肝線維症は正常肝に近いパターンを示し たのに対し, 䀒硬变症での MI 值はより低值で, 畈障害 の程度が強くなるにつれ分裂数が減少し細胞回転が悪 くなる傾向がらかがわれた。な打1核，2核細胞に分 けて分裂像を検討することは HE 染色標本では極め て困難であった。

一方，BrdUを投与すると BrdUが取り込まれた S 期細胞は明確に識別され，1核，2核細胞に分けて険 討することが容易である.そこで, BrdU を用いて障害 肝の肝切後の肝再生時におけける 1 核，2核細胞それぞ れの LI 值の変動について険討した結果, 障害肝の 1 核細胞は正常肝之同様肝切24時間後が最も高く，以後 漸減する経過を示したが，肝線維症と肝硬変症に分け ると; 肝線維症では正常肝に近く，肝硬変症では低值 を示し，肝障害の程度が強くなるにつれ１核細胞の
LI 値は低值を示す傾向にあった。 また肝線維症では肝 切48時間後, 肝硬変症では肝切 24 時間以後の LI 值は 急速に低值を示し，障害肝の肝切除後は比較的早期か ら細胞回転が悪くなる傾向がみられた。 2 核細胞の LI は障害肝では正常肝に比べ肝切後の標識率が悪く，最 む BrdU のとり込みの高い肝切24時間後です正常肝 の $1 / 3$ 程度で, 肝線維症, 肝硬变症に分けてみても差は みられず，肝切後早期に細胞回転が悪くなる傾向に あった。このよらに障害肝では 1 核， 2 核細胞，こと に2 核細胞の細胞回転が悪い傾向にあったが，かかる 際の 2 核細胞の分裂増殖形態はなお明かでない，今回 の恰討です， 2 核細胞の分裂像や BrdU を取り込んだ $\mathrm{S}$ 期 2 核細胞はみられるすのの，分裂後の細胞をとら 光ることができなかった，今後電顕的あるいは 2 核細 胞のみの肝細胞培盖などでの検討が必要と思われる。 肝再生時の 2 核細胞の役割汇関して, 松田ら ${ }^{14)}$ は肝細 胞の polyploidy 化に伴って 2 核細胞が減少すること， galactosamine 投与による肝炎モデルでは 2 核細胞の 減少がなく， polyploidization もわずかしかみられな かったこと，また Nadal ら ${ }^{18) か ゙ ~} 2$ 核細胞のみられない 生後 3 週までのラットでは polyploidization がみられ ないと報告していることなどより2核細胞が肝細胞の polyploidy 化に密切な関係があるものと推測してい る. しかし 2 核細胞に接している 1 核細胞に BrdU の とり込みが多いこともなく， polyploidy 化の機序は明 かでない，今後 1 核，2核細胞を分離し，1核，2核 細胞各々の培養あるいは 1 核， 2 核細胞の混合培養な どにより1核細胞と 2 核細胞の関係について検討する ことも必要と思われる。，一方，障害肝の肝細胞では一 般に肝細胞膜機能の変化や肝細胞でのエネルギー消費 の低下により DNA の合成が抑制されるといわれてい

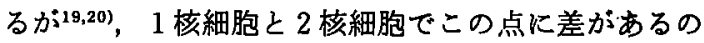
か検討することも必要であろう。さらに今回著者らが 用いた DEN は主としてDNA 合成を阻害する薬剤で あることから， $\mathrm{CCl}_{4}$ ，TAA など他の薬剤による肝障害 での検討わ必要であろう。

\section{結 語}

DENを用いて作成した肝線維症, 肝硬变症ラット の70\%肝切除後の肝再生時における1核， 2 核細胞の 細胞動態について検討し以下の成績をえた。

1. 肝切後の MI は肝障害の程度が強くなるにつれ 低值となる傾向がみられた，

2. BrdUによる1核細胞の LI は肝切後, 肝障害の 程度が強くなるはど低値となり肝再生が悪くなる傾向 
がみられた。

3. 2 核細胞の LIは肝障害の程度による差が少な く，正常肝より低値で, 肝再生への関与が少ないよう に思われた。

なお本論文の要旨は第74回日本消化器病学会総会で報告 した.

\section{文 献}

1) Lin TY, Lee CS, Chen CC, et al: Regeneration of human liver after hepatic lobectomy studied by repeated liver scanning and repeated needle biopsy. Ann Surg $190: 48-53,1979$

2) 下山孝俊, 福田 豊, 原田達郎, 他：肝硬変並存肝 癌に対する外科的治療の問題点. 日消外会誌 19 : 1942-1951, 1986

3）蔡 栄若, 山下隆史, 芳野裕明, 他：肝再生過程に おける 1 核, 2 核肝細胞の細胞動熊に関する BrdUならびにヒストグラムバーンによる検 討. 肝䁍 $30: 522-528,1989$

4) 滝野辰郎, 香川恵造, 出口武司 : 実験肝癌, 図説臨 床癌シリーズ 3 肝癌, 末年恵一, 高山昭三, 豊島久 真男, 外編, メジカルビュー社, 東京, 1986, p165 $-171$

5）寺尾征史：膵 島構成細胞の組織計測的分析一肝 硬变症を中心として一。阪市医誌 $37: 127-145$, 1988

6) Higgins GM, Anderson RM: Experimental pathology of the liver; 1 . Restoration of the white rat following partial surgical removal. Arch Pathol 12: 186-202, 1931

7) Madden JW, Gertman PM, Peacock EE Jr: Dimethylnitrosamine-induced hepatic cirrhosis : A new canine model of an ancient human disease. Surgery $68: 260-268,1970$

8）多田利彦，児玉哲郎，渡辺昌，他：BrdU (Bromodeoxyuridine)モノクローナル抗体を用い た細胞動態解析法の基礎的検討とその臨床応用. 医学のあゆみ $135: 510-513,1985$
9) Gratzner HG: Monoclonal antibody to 5brom and 5-iododeoxyuridine: A new reagent for detection of DNA replication. Science 218 : $474-475,1982$

10）河合庸仁：再生過程における肝の容積 と機能の変 化の相関に関する実験的, 臨床的研究. 日外会誌 $85: 1317-1331,1984$

11）鈴木寛路：硬变肝切除後の質的，および量的肝再 生に関する実験的研究. 愛知大学医学会誌 13 : 483-497, 1985

12）舟木昭蔵：実験的硬変肝の再生に関する研究. 北 海道医学雑誌 $40: 274-284,1965$

13）山口秀則, 草野満夫, 水戸抽郎：肝再生時に括ける 肝細胞扎よび Kupffer 細胞の細胞回転一フローサ イトメトリーによる解析一。肝藏 29：1068 $-1077,1988$ 。

14）松田健志，小田島肃夫：肝細胞の堌殖動態につい て. 肝藏 $27: 1303-1312,1986$

15）鈴木陽一：ヒト慢性肝疾患㧍よび Diethyl一 nitrosamine による発癌過程ラット肝の feulgen DNA 量の検討。信州医誌 $30: 609$-620, 1982

16) Sater G, Schwarze PE, Seglen PO : Shift from polyploidizing to non-ploidizing growth in treated rat liver. J Narion Cancer Institute 80 : 950-958, 1988

17) Wheatley DN : Binucleation in mammalian liver. Exptl Cell Res 74 : 455-465, 1972

18) Nadal C, Zajdela F: Polyploidie somatique dans le foie de rat. I. Le role des cellules binuclees dans la genese des cellules polypolides. Exp Cell Res 42 : 99-116, 1966

19）平石 深, 大柳治正, 斉藤洋一：障害肝切除前後の 病態生理と肝予備能把握に関する研究，神戸大学 紀要 $45: 105-119,1984$

20）吉川高志：高度障害肝に対する膵ホルモンの有効 性に関する基礎的研究一Dimethylnitrosamine ラット硬変肝肝切除後の残存肝に対する脺ホルモ ンの有効性に関する実験的研究.日消外会誌 18 : $2030-2040,1985$ 


\title{
The changes of cell kinetics of uni- and binucleated hepatocytes after partial hepatectomy in DEN induced chronic liver injured rats
}

\author{
Tsai Jung Rou, Takafumi Yamashita, Hiroaki Yoshino, Yasuko Yamada, \\ Kazuhiko YoshIKawa, Tetsuro IshIKawa, Masaichi OHIRA, \\ Takashi AzUMA and Kaoru UMEYAMA*
}

We produced diethylnitrosamine induced chronic liver injury in rats. These rats were divided morphologically into two groups: liver fibrosis and liver cirrhosis group. Then we examined cell kinetics of uni- and binucleated hepatocytes after hepatectomy $(\mathrm{Hx})$ using antibromodeoxyuridine monoclonal antibody. The values of labeling indices (LIs) of uninucleated hepatocytes in liver fibrosis group were higher than those in liver cirrhosis one. But the values of LIs of binucleated cells in both groups after $\mathrm{Hx}$ were lower than those in normal liver.

From the above results, it is suggested that binucleated hepatocytes in chronic injured liver do not participate in liver regeneration.

* First Department of Surgery, Osaka City University Medical School (Osaka) 